\title{
Subcolony variation in phenology and breeding parameters in little auk Alle alle
}

\author{
Dariusz Jakubas • Katarzyna Wojczulanis-Jakubas
}

Received: 22 March 2010/Revised: 21 June 2010/Accepted: 22 June 2010/Published online: 3 July 2010

(c) Springer-Verlag 2010

\begin{abstract}
In seabirds, variation in breeding phenology and success is often induced by macro- and mesoscale fluctuations in oceanographic conditions, which is recordable at the regional or colony scale. Variation in breeding parameters may also exist at the microscale-among discrete breeding aggregations and subcolonies. The aim of this study was to compare breeding phenology and parameters (hatching success, chick survival, chick body mass indices) among little auks (Alle alle) nesting in three subcolonies differing in their microtopographic and microclimatic features, situated in Magdalenefjorden (north-western Spitsbergen). The hatching phenology varied significantly among the subcolonies. This was probably due to the different duration of snow persistence in spring, as nests are occupied as soon as the snow cover melts sufficiently to allow access to them. The earliest hatching was recorded in the subcolony located on steep slopes at low altitude in the vicinity of the fjord, which favours early ice and snow melting in spring. Hatching success differed significantly among subcolonies, which could also have been due to the microclimatic features of the subcolonies. Hatching success was the lowest in the subcolony where birds started to breed while patchy snow was still persisting. Water from the melting snow could have flooded some of the nests. Alternatively, the low hatchability could have been caused by a higher frequency of less experienced breeders (e.g., first-time breeders) among the individuals nesting in this subcolony. Other breeding parameters (chick survival and growth) were generally similar in all the subcolonies.
\end{abstract}

D. Jakubas $(\bowtie) \cdot$ K. Wojczulanis-Jakubas

Department of Vertebrate Ecology and Zoology,

University of Gdańsk, al. Legionów 9, 80-441 Gdańsk, Poland

e-mail: biodj@univ.gda.pl
Keywords Subcolony · Breeding success · Chick growth $\cdot$ Phenology $\cdot$ Arctic $\cdot$ Little auk

\section{Introduction}

In many species of seabirds, breeding phenology and success vary spatially and temporally. This variation is induced by macroscale fluctuations of oceanographic conditions (e.g., North Atlantic Oscillation, El Niño Southern Oscillation; Stenseth et al. 2003) as well as mesoscale processes (e.g., sea ice dynamics, sea current distribution, upwelling strength and spread, atmospheric blocking; Kitaysky and Golubova 2000; Harding et al. 2003; Adams et al. 2004; Gaston et al. 2005, 2009; Sydeman et al. 2006; Grémillet et al. 2008; Moline et al. 2008; Shultz et al. 2009). These phenomena affect marine food webs, among other things, by changes in species composition and shifts in their phenology. Seabirds may experience temporal and/ or spatial changes in the availability of food. Reduced food availability often causes higher stress level, slower chick growth and lower breeding success (e.g., Hedd et al. 2002; Durant et al. 2003, 2007; Gjerdrum et al. 2003; Abraham and Sydeman 2004; Kitaysky et al. 2007; BenowitzFredericks et al. 2008; Hipfner 2008; Gaston et al. 2009). Macro-scale effects of oceanic fluctuations or perturbations are visible at a regional or colony scale. Variations in breeding success and phenology may also exist at the microscale-among discrete breeding aggregations (hereafter "subcolonies"). This may be due to the different age and social structure of breeding birds, foraging strategies, predation rates, microtopograhic and microclimate conditions (Tenaza 1971; Morbey and Ydenberg 1997; Rodway et al. 1998; de Neve et al. 2006; Suryan et al. 2006; Hipfner et al. 2007, 2010; Tavecchia et al. 2008). The influence of 
macro- and mesoscale phenomena on breeding success and phenology in seabirds has been widely documented in recent years, in contrast to less studied microscale effects, e.g., subcolonial.

The little auk (Alle alle) is a planktivorous seabird that breeds in the high Arctic and lays a single egg annually. It nests in colonies situated mainly on unvegetated scree on mountain slopes of $25-35^{\circ}$ inclination. As the scree on a slope forms a patchy pattern, breeding colonies are divided into variably sized subcolonies. The timing of breeding of little auks is strongly determined by snow melting in spring, which allows birds to enter the nest (Cramp 1998; Stempniewicz 2001; Moe et al. 2009).

The aim of this study was to compare the breeding phenology and parameters (reproductive success, chick growth) among three subcolonies varying in their microtopographic characteristics. Since microclimatic conditions, including the distribution of snow and its persistence in spring, are affected by microtopographic features, such as altitude (air temperature gradient), aspect (different insolation on slopes with different exposure), inclination (a steep slope has a thinner snow cover) and also wind operation (affecting the accumulation/redistribution of snow) (e.g., Elder et al. 1991; Szor et al. 2008), we hypothesized that the timing of breeding varies among different parts of the colony. As the birds breeding in different subcolonies very probably forage in the same oceanographic conditions, any inter-subcolony differences in phenology or breeding success should be attributed to microclimatic conditions, quality of nest sites and quality of individuals. Reproductive success declines over the course of the breeding season in many bird species, including alcids (Hatchwell 1991; de Forest and Gaston 1996; Hipfner 1997; Rodway et al. 1998; Hipfner et al. 2010). If the timing of breeding varies among the subcolonies, differences in breeding parameters may be expected. Prior to this study, within-colony variation in breeding phenology and parameters in the little auk was mentioned by Evans (1981), but it had not been studied in detail. Stempniewicz $(1986,1995)$ compared among subcolonies only the rhythm of attendance and chick mortality caused by gull predation.

\section{Materials and methods}

The study was carried out in the little auk breeding colony on the northern side of Magdalenefjorden, NW Spitsbergen $\left(79^{\circ} 35^{\prime} \mathrm{N}, 11^{\circ} 05^{\prime} \mathrm{E}\right)$ from 11 July to 15 August 2008 and from 10 July to 15 August 2009 (the late incubation and chick-rearing periods). Magdalenefjorden is considered to be one of the largest breeding aggregations of this species in Spitsbergen (Isaksen 1995). Three spatially separated colony patches (subcolonies) situated on the Alkekongen and Høystakken slopes and on the side moraine of the Buchanbreen glacier slope (hereafter 'Moraine'; Fig. 1) were monitored. We chose those subcolonies because they differed in their topographic features (Table 1) and had been described as containing a large number of breeding pairs (Isaksen 1995). The Høystakken subcolony was situated 1,255 $\mathrm{m}$ from Moraine and 1,355 $\mathrm{m}$ from Alkekongen. A distance of $140 \mathrm{~m}$ separated the latter two subcolonies. The Høystakken and Moraine subcolonies were similar in area, whereas the Alkekongen subcolony covered a smaller area (Table 1). The exact position of each subcolony was located using a global positioning system (GPS) receiver $( \pm 10 \mathrm{~m})$. Certain topographic features were recorded/calculated on the basis of GPS data (altitude, distance, area). Slope inclination was measured with a protractor from photographs. A similar number of nests were monitored within each subcolony (Table 1).

Hatching phenology, chick growth and breeding success were compared among the three subcolonies. Hatching dates were estimated during regular visits (every 2 days) to the group of 30-60 inspected nests, from late incubation until the end of hatching within the group of monitored nests. Since the majority of nests $(88 \%)$ at Moraine were found in 2008 after hatching, the dates of hatching for these nests were back-calculated from an estimate of chick growth. Two regression functions were used for that purpose. The functions were derived from measurements of other chicks examined from the first days of their life in the same and other subcolonies. The following standard measurements of chicks were made (carpometacarpus length, flattened wing length, head-bill length, bill width, tarsus length) with dial calipers (accurate to $0.1 \mathrm{~mm}$ ) by the same

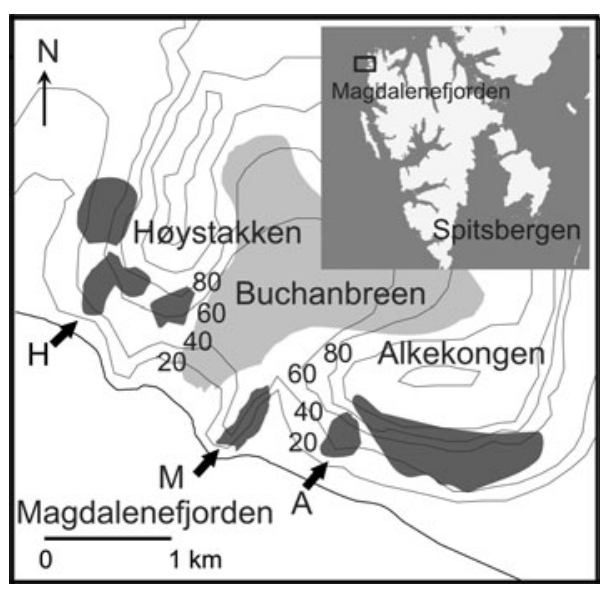

Fig. 1 Study area in Magdalenefjorden. The grey patches indicate subcolonies of the little auk, the arrows and letters the subcolonies studied (A-Alkekongen, M-Moraine, H-Høystakken). The light grey area indicates a glacier. Map drawn on the basis of a Norsk Polar Institutt map. The numbers next to isohypses indicate altitudes 
Table 1 Characteristics of the three little auk subcolonies in Magdalenefjorden

\begin{tabular}{llll}
\hline Parameter & Subcolony & & Hoystakken \\
\cline { 2 - 4 } & Alkekongen & Moraine & South \\
\hline Aspect & South & East & $25-35$ \\
Slope inclination $\left(^{\circ}\right)$ & $30-40$ & $35-40$ & Min $42 \mathrm{~m}$, max $86 \mathrm{~m}$, \\
Altitudes (above mean sea level) & Min $35 \mathrm{~m}, \max 67 \mathrm{~m}$, & Min $16 \mathrm{~m}$, max $51 \mathrm{~m}$, & midde point: $61 \mathrm{~m}$ \\
& middle point: $51 \mathrm{~m}$ & middle point: $34 \mathrm{~m}$ & $1,111 \mathrm{~m}^{2}$ \\
Area & $754 \mathrm{~m}^{2}$ & $1,263 \mathrm{~m}^{2}$ & $45 / 59$ \\
No. of nests studied $(2008 / 2009)$ & $37 / 32$ & $42 / 66$ & The outermost \\
Location in the fjord & The innermost & Middle & - \\
Other features & - & Well protected against west winds by moraine & -
\end{tabular}

worker every 3 days. Among the parameters, carpometacarpus and head-bill length were the best correlated with age (carpometacarpus: $r=0.97, d f=212, P<0.001$, $R^{2}=0.94$, head-bill-length: $\quad r=0.96, \quad d f=252, \quad P<$ $\left.0.001, R^{2}=0.93\right)$. Hatching dates were estimated based on average values calculated from two functions (f1: day of life $=-8.51+0.517 *$ carpometacarpus length, f2: day of life $=-46.37+1.474 *$ head-bill length).

The body mass of chicks, the parameter least biased by human measurement error, was used to compare chick growth among the subcolonies. It has been demonstrated that body mass in little auk chicks may act as a direct measure of parental resource allocation between selfmaintenance and current reproduction (Harding et al. 2009). Chicks were weighed with an electronic balance (accurate to $0.1 \mathrm{~g}$ ) every 3 days after hatching (2008) and every 2 days after the 14th day of life (2009) until they left the nest (at the age of 25-27 days, Stempniewicz 1981; Harding et al. 2004). Four chick body mass parameters were analysed: body mass on the 14-15th day of life, peak mass (the highest mass noted per chick), fledging mass (the last mass measured before the chick's departure from the colony) and mass recession (difference between peak and fledging mass; after Stempniewicz 1980; Konarzewski and Taylor 1989). The day when peak mass was achieved and the day of fledging (the last presence in the nest) were also compared among the subcolonies. At the age of 14-15 days, chicks begin to exercise their wings outside the nest chamber (Stempniewicz 1995). Thus, until that age chicks remain in the nest, expending energy mainly on growth and thermoregulation. The peak and fledging masses have been found to be effective growth indicators, even more efficient than the widely used growth-curve analysis (Zach 1988).

Four parameters of breeding success were calculated: hatching success (number of chicks hatched/number of eggs monitored), breeding success up to 14 days (number of chicks 14 days old/number of eggs monitored), chick survival up to 14 days (number of chicks 14 days old/ number of chicks hatched; chicks at that age start to appear outside nest chamber, becoming more vulnerable to predation; Stempniewicz 1995), chick survival up to 20 days (number of chicks 20 days old/number of chicks hatched; chicks that disappeared from the nest after 20 days were assumed to have fledged; Harding et al. 2004; Welcker et al. 2009). Because the study was completed before all the chicks the whole colony fledged, data on chick survival up to 20 days and on body mass after 14 days were available only for some subcolonies (Tables 2 and 3). To investigate the reasons for hatching failures, we classified lost eggs as abandoned (a cold egg found during two consecutive visits after inspections with adult/warm egg present), failed to hatch (dead embryo found in posthatching egg shell), predated (empty nest with faeces and scent of the arctic fox Alopex lagopus), caved in (nest with egg destroyed by stones) and unknown (lack of egg and adult). Breeding success was also compared between nests of early (egg hatched before the overall colony median date) and late (egg hatched after the overall colony median date) breeders, from all subcolonies combined. All tests were calculated using STATISTICA 8.0.

The occurrence of snow events and the duration of thawing during the study period (late incubation and chickrearing period) were systematically observed and recorded. To estimate the duration of snow persistence in the three subcolonies in spring, two temperature loggers (Maxim Integrated Products, Inc., CA, USA) were deployed close to the nests in each subcolony at the end of the fieldwork in 2008 for measuring ground temperature in May-June 2009. They were buried in the soil at a depth of $4 \mathrm{~cm}$ in the central parts of the subcolonies at altitudes similar to the middle points presented in Table 1. The loggers measured the temperature every $4 \mathrm{~h}$. We analysed and presented the mean daily values for the period from 29 April to 12 July, representing the little auk's pre-laying, egg-laying and incubation periods. 
Table 2 Chick growth parameters recorded in the three little auk subcolonies

\begin{tabular}{llllcc}
\hline Subcolony & Year & $\begin{array}{l}\text { Body mass on the } \\
\text { 14-15th day }[\mathrm{g}]\end{array}$ & Peak mass $[\mathrm{g}](\mathrm{A})$ & Fledging mass [g] (B) & Mass recession [g] (A-B) \\
\hline Alkekongen & 2008 & $107.5 \pm 10.97(6)$ & - & - & - \\
& 2009 & $115.5 \pm 6.26(10)$ & $124.0 \pm 3.54(6)$ & - & $112.6 \pm 10.79(22)$ \\
Moraine & 2008 & $110.5 \pm 9.30(11)$ & $125.6 \pm 8.33(25)$ & $113.0 \pm 6.49(19)$ & $14.3 \pm 7.70(17)$ \\
& 2009 & $110.6 \pm 8.31(19)$ & $125.3 \pm 10.70(23)$ & $118.7 \pm 9.47(7)$ & $15.3 \pm 9.24(7)$ \\
Høystakken & 2008 & $112.9 \pm 11.76(13)$ & $134.4 \pm 9.34(8)$ & - & - \\
\hline
\end{tabular}

Numbers indicate mean \pm SD (sample size)

Table 3 Hatching and breeding success in the three little auk subcolonies (unhatched eggs excluded from chick survival, included in breeding success up to 14 days)

\begin{tabular}{|c|c|c|c|c|c|}
\hline \multirow[t]{2}{*}{ Year } & \multirow[t]{2}{*}{ Subcolony } & \multirow{2}{*}{$\begin{array}{l}\text { Hatching } \\
\text { success }(N)\end{array}$} & \multirow{2}{*}{$\begin{array}{l}\text { Breeding success } \\
\text { up to } 14 \text { days }(N)\end{array}$} & \multicolumn{2}{|c|}{ Chick survival $(N)$} \\
\hline & & & & Up to 14 days & Up to 20 days \\
\hline \multirow[t]{3}{*}{2008} & Alkekongen & $81 \%(37)$ & $66 \%(29)$ & $86 \%(22)$ & - \\
\hline & Moraine & $95 \%(42)^{\mathrm{a}}$ & $86 \%(42)$ & $90 \%(40)$ & $92 \%(36)$ \\
\hline & Høystakken & $71 \%(45)^{\mathrm{a}}$ & $68 \%(40)$ & $100 \%(27)$ & $100 \%$ \\
\hline \multirow[t]{3}{*}{2009} & Alkekongen & $88 \%(32)^{\mathrm{c}}$ & $79 \%$ (29) & $92 \%(25)$ & $82 \%(11)$ \\
\hline & Moraine & $86 \%(66)^{b}$ & $73 \%(62)$ & $85 \%(53)$ & $80 \%(51)$ \\
\hline & Høystakken & $66 \%(59)^{\mathrm{b}, \mathrm{c}}$ & $62 \%(53)$ & $100 \%(33)$ & $100 \%(24)$ \\
\hline
\end{tabular}

$N$ number of nests studied

Significant differences between particular subcolonies $(2 \times 2$ Fisher's exact test $):{ }^{\mathrm{a}} P=0.004 ;{ }^{\mathrm{b}} P=0.01 ;{ }^{\mathrm{c}} P=0.05$

\section{Results}

Snow conditions and ground temperature

Sudden and intensive snowfall was recorded during late incubation in 2008 (11-12 July) in the study area. All the subcolonies were covered with snow (for at least 4 days), whereas during the same period in 2009 there was no snow cover. After the snow event in July 2008, the Moraine subcolony was the first to become snow free. In the two other subcolonies, snow persisted throughout the next few days, in some places even until the third decade of July.

The mean ground temperatures recorded during the prelaying, egg-laying and incubation periods in 2009 differed significantly among the subcolonies (Kruskal-Wallis test, $H=34.90, d f=2,228, P<0.0001$; Fig. 2), and those recorded at Moraine were significantly higher than at Høystakken and Alkekongen (Dunn test, $P<0.005$ ). In all the subcolonies, the mean ground temperature rose above $0^{\circ} \mathrm{C}$ in the first week of May (Fig. 2). After the few next days of generally higher temperatures, it dropped at Høystakken to $0^{\circ} \mathrm{C}$ on 16 May and remained at that level until 21 June. In the same period, the temperature in the two other subcolonies rose to $3-7^{\circ} \mathrm{C}$, dropping to $0^{\circ} \mathrm{C}$ and even below zero only for short periods (up to 3 days).
At the time when the little auks started to lay eggs, mean ground temperatures at Moraine and Alkekongen rose to above $5^{\circ} \mathrm{C}$. Only at Høystakken did the temperature rise above $0^{\circ} \mathrm{C} 4$ days after the beginning of egg-laying (Fig. 2).

\section{Hatching phenology}

Hatching dates differed significantly among the subcolonies in 2008 (Kruskal-Wallis tests, $H=51.7, d f=2,95$, $P<0.001)$ and $2009(H=64.2, d f=2,120, P<0.001)$. The earliest hatching was recorded in the Moraine subcolony (median dates: 16-17 July; Fig. 3). Birds from the two others hatched significantly later (2008-2009: median dates: 24-27 July at Høystakken and 27 July-1 August at Alkekongen; Dunn test, for 2008 and 2009: Alkekongen vs. Moraine and Høystakken vs. Moraine, $P<0.001$, Fig. 3). There was a significant difference in hatching dates between Høystakken and Alkekongen in 2008 (Dunn test, $P=0.01$ ), but in 2009 these dates were similar (Dunn test, $P>0.05$; Fig. 3).

Hatching dates in all the subcolonies combined were similar in 2008 (median: 25 July) and 2009 (median: 22 July; Mann-Whitney $U$ test, $Z=1.45, N=95,120$, $P=0.15)$. However, considering the subcolonies separately, 
Fig. 2 Mean daily ground temperatures $\left({ }^{\circ} \mathrm{C}\right)$ recorded in the three subcolonies during the pre-laying, laying and incubation periods in 2009. The lines on the graph indicate estimated ranges of egg laying [dates back-calculated from the hatching dates and the length of the incubation period (29 days; Stempniewicz 1981)] in the three subcolonies

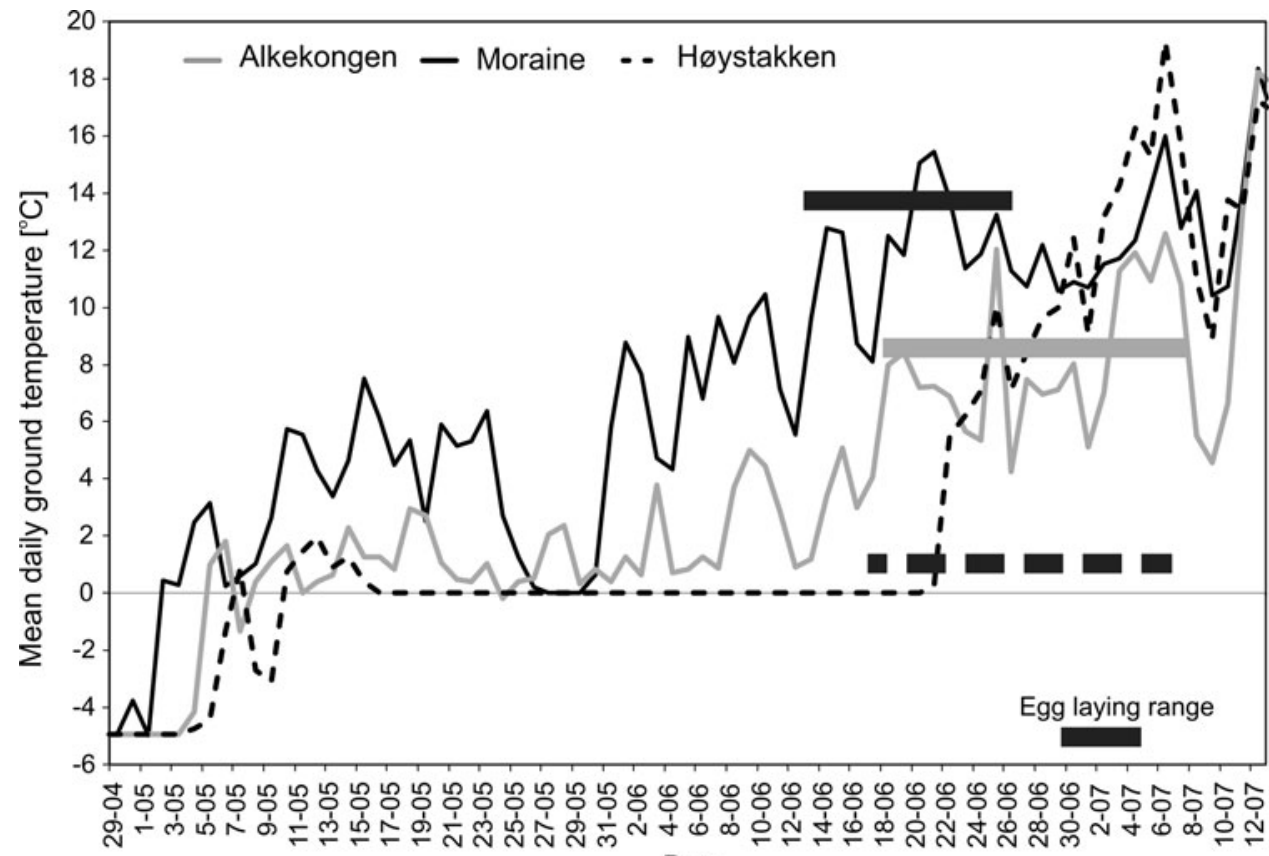

Date

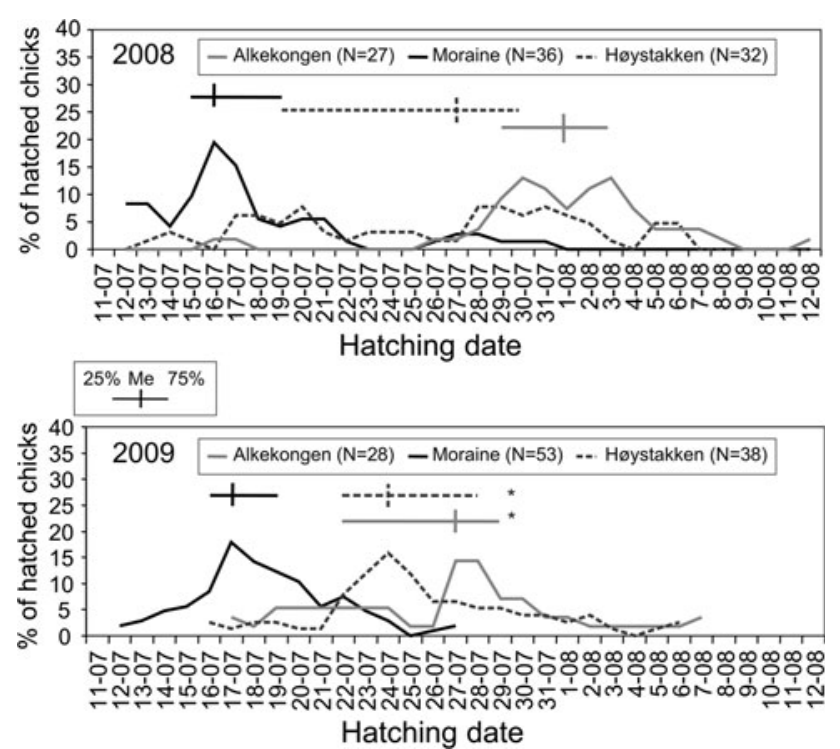

Fig. 3 Hatching dynamics (moving average with a period of 2 days) in the particular subcolonies of little auk in Magdalenefjorden in 2008-2009. The lines above the graphs indicate the $25-75 \%$ quartiles and median (vertical line), the asterisks indicate a lack of significant inter-subcolony differences in phenology (Dunn test, $P>0.05$ )

phenological shifts between the seasons were recorded at Moraine (median hatching date earlier by 1 day in 2008, $Z=-2.20, \quad N=36, \quad 54, \quad P=0.03)$ and Alkekongen (median hatching date earlier by 4 days in 2009, $Z=4.01$, $N=27,28, P<0.001)$. Only at Høystakken, despite the 4-day difference between median dates, the distributions of the hatching dates were similar in both seasons ( $U$ test: $Z=0.33, N=32,38, P=0.74$ ) (Fig. 3). Nests of late breeders (whose eggs hatched after the overall colony median date) made up 95 and $75 \%$ of all the nests inspected at Alkekongen, 10 and $8 \%$ at Moraine and 46 and $87 \%$ at Høystakken, in 2008 and 2009, respectively.

Generally, one quite well-pronounced hatching peak was observed at Alkekongen and Moraine in 2008 and in all three subcolonies in 2009. At Høystakken in 2008, two smaller peaks were recorded at the time of the peak occurrence at Moraine and Alkekongen. In both seasons, the hatching peak at Moraine was more advanced than in the other subcolonies. However, hatching dates in the subcolonies overlapped strongly (Fig. 3). At the subcolony scale, hatching lasted 19 and 14 days at Moraine, 23 and 20 days at Høystakken and 27 and 25 days at Alkekongen in 2008 and 2009, respectively. In all the subcolonies combined, hatching in 2008 lasted 32 days, i.e., 7 days longer than in 2009 ( 25 days).

\section{Chick body mass}

Two-factor ANOVA of the body mass of 14- to 15-day-old chicks versus year and subcolony showed no significant effect of either factor (year, $F=1.07, d f=1, P=0.30$; subcolony, $F=0.30, d f=2, P=0.74)$ or interaction $(F=1.14, d f=2, P=0.32)$. Two-factor ANOVA of peak chick body mass versus year and subcolony (excluding Alkekongen-insufficient sample size in 2008) revealed a significant subcolony effect $(F=4.47, d f=1$, $P=0.04)$. The effects of the year $(F=2.21, d f=1$, $P=0.14)$ and interaction $(F=1.87, d f=1, P=0.18)$ were not significant. The peak chick body mass recorded at 
Høystakken was significantly higher than that at Moraine (Table 2). In 2009, peak body mass at Alkekongen was similar to that recorded at Moraine (Student's $t$ test, $t=0.27, d f=27, P=0.79$ ) and Høystakken (MannWhitney $U$ test, $U=34.0, N=6,14, P=0.51)$. Fledging mass was similar at Høystakken and Moraine in 2008 (Student's $t$ test, $t=1.34, d f=27, P=0.19$ ) and at Moraine in both seasons $(t=-0.14, d f=39, P=0.88$; Table 2). Likewise, no differences were found for body mass recession. Similar values were recorded at Høystakken and Moraine in 2008 (Student's $t$ test, $t=0.44, d f=27$, $P=0.66)$ and at Moraine in both seasons $(t=-0.21$, $d f=37, P=0.83$; Table 2 ). None of the body mass parameters was related to the hatching date (Pearson correlation coefficients for all colonies combined in 2008 and 2009- $P>0.10$ ).

Peak body mass was achieved by chicks at a similar mean age at Moraine (19.8 \pm 2.12 day of life) and Høystakken (19.7 \pm 2.73 days) in 2008 (Student's $t$ test, $t=0.07, d f=31, P=0.95)$. The pattern in 2009 was much the same (Høystakken: $19.6 \pm 2.76$ days; Moraine: $20.1 \pm 2.40$ days; $t=-0.57, d f=35, P=0.57)$. No interannual difference was found in the day peak body mass was achieved, either at Moraine $(t=-0.60, d f=46$, $P=0.55)$ or Høystakken $(t=0.09, d f=20, P=0.93)$. In 2008, chicks were recorded for the last time in their nests at a similar mean age at Moraine (25.0 \pm 1.72 days) and Høystakken $(25.1 \pm 1.35$ days; Student's $t$ test, $t=-0.20, d f=27, P=0.84)$. On the fledging day at Moraine in 2009, chicks had a mean age of $24.7 \pm$ 1.41 days. There was no significant difference in the day of the last presence of the chick in the nest between the seasons at Moraine ( $t=0.53, d f=39, P=0.60$ ).

\section{Breeding success}

In both seasons, the percentage of successfully hatched chicks was $>80 \%$ at Moraine and Alkekongen and was significantly higher than at Høystakken (Fisher's exact test, Table 3). Despite the differences in hatching success, the reasons for egg losses were similar in all subcolonies. Over $60 \%$ of eggs failing to hatch had been abandoned by the parent birds. In $27 \%$ nests, the reason for hatching failure was unknown (Table 4). The proportion of eggs failing to hatch as a result of abandonment was similar in all the subcolonies (both seasons combined, $G$ test, $G=0.01$, $d f=3, P=0.99)$. Also, the proportion of nests with an unknown reason for egg loss was similar in all the subcolonies ( $G$ test, $G<0.001, d f=3, P=0.99$ ). A breeding success up to 14 days, chick survival up to 14 and 20 days were similar in all the subcolonies in both seasons (Table 3). In each subcolony, all breeding success parameters were similar in both seasons (Fisher's exact test, $P>0.05$ ). Chick survival up to 14 days of life in all subcolonies combined was similar in both seasons in early (hatched before the median date, 2008: 96\%, $N=50$, 2009: $88 \%, N=58$ ) and late broods (chicks hatched after the median date, 2008: $86 \%, N=37 ; 2009: 93 \%, N=46$; Fisher's exact test, 2008: $P=0.13,2009: P=0.51)$.

\section{Discussion}

The present study shows that hatching phenology and success of little auks varied within the colony and that these parameters were probably related to the microclimate produced by microtopographic features. The sequence of median hatching dates in the three subcolonies (Moraine, Høystakken/Alkekongen) seems to be consistent with the pattern of snow melting in July 2008 and in spring 2009 (assuming that the mean ground temperatures $\leq 0^{\circ} \mathrm{C}$ recorded by the loggers in May-June 2009 reflect the presence of snow cover on the ground; Fig. 2). The easterly orientation (the lowest insolation) of the earliest hatching subcolony at Moraine and the fact that this locality is protected against westerly winds and blizzards favour the accumulation of snow during a long winter. However, access to the nests was the earliest in low altitude locations in the vicinity of fjord waters and on steep slopes (higher air temperatures and thaw rate in spring). Breeding at Høystakken and Alkekongen started significantly later in both seasons. Despite the southerly orientation (linked to the warmer microclimate due to strong insolation; Szor et al. 2008), both these subcolonies were located at higher altitudes, which meant lower air temperatures. With no protection against winds and blizzards, snow is readily

Table 4 Reasons for egg losses in the three little auk subcolonies in all seasons combined

\begin{tabular}{lllllll}
\hline Subcolony & Egg abandonment & Failed hatching & & \multicolumn{2}{l}{ Reasons for egg losses (\%) } \\
\cline { 5 - 7 } & & & Predation & Nest caved in & Unknown & No. of nests \\
\hline Alkekongen & 63.6 & 9.1 & - & - & 27.3 & 11 \\
Moraine & 63.6 & 9.1 & - & - & 27.3 & 11 \\
Høystakken & 60.6 & 6.1 & 3.0 & 3.0 & 27.3 & 33 \\
All combined & 61.8 & 7.3 & 1.8 & 1.8 & 27.3 & 55 \\
\hline
\end{tabular}


blown away, uncovering nesting sites. However, as snow persisted the longest in those subcolonies after the July 2008 snowfall, the lack of protection against winds and blizzards may tend to favour the local accumulation of redistributed snow (reflected in Høystakken by long period when the recorded mean ground temperature was $0^{\circ} \mathrm{C}$ ), which delays nest accessibility in spring.

Hatching success differed significantly among the subcolonies, which may have been due to the microclimatic features of the subcolonies. In both seasons, hatchability was lowest at Høystakken. The temperatures recorded there at the time when the birds started to breed were considerably lower than in the other subcolonies. This suggests that the little auks at Høystakken started to incubate when the snow still persisted in patches. As a consequence, water from melting snow could have flooded some of the nests in this subcolony. After the intensive snowfall in July 2008, we found cold, wet eggs inside three nests at Høystakken. In the Atlantic puffin (Fratercula arctica), nest burrow flooding after intense rainfall reduced the hatchability of eggs (Rodway et al. 1998). In the present study, hatching success was not particularly affected by egg predation, as most eggs that had failed to hatch were found abandoned in the nest in all the subcolonies. Even if predation was responsible for the egg losses for unknown reasons, its rate did not vary among the subcolonies. Moreover, investigator disturbance, adversely affecting the hatching success of little auks (Stempniewicz 1995), was similar in all the subcolonies. Hatching success is often lower in the nests of young birds (Koenig 1982) and of individuals in poor body condition (Yorio and Boersma 1994) or with high stress levels during incubation due to prior nutritional stress (Kitaysky et al. 2007). Young and/or 'low-quality' individuals often occupy worse, peripheral parts of colonies (e.g., Spurr 1975; Mínguez et al. 1998; Gibbs et al. 2000). The southern part of Høystakken is a peripheral part of the colony. If this subcolony had been occupied mainly by young and/or 'low-quality' individuals, their low experience/poor condition might have explained the low hatchability. At present, we are unable to conclude whether it was the quality of individuals or the micro-climatic conditions that were responsible for different hatching success rates in the subcolonies. These two possibilities are not mutually exclusive, i.e., worse quality individuals may be forced to breed in parts of a colony with a less favourable microclimate. The results presented here are an important basis for further investigations into this subject.

The temporal extension of breeding in Magdalenefjorden could cause a mismatch between the timing of reproduction and the annual peak in food availability (cold-water copepods) for early and/or late breeders. In the planktivorous Cassin's auklet (Ptychoramphus aleuticus), breeding success is determined largely by breeding being synchronous with the main prey item biomass peak (Hipfner et al. 2010). The dynamics of the availability of little auk's preferred prey in the study area is unknown. However, intersubcolony differences in the timing of breeding generally did not result in any differentiation in chick growth or survival. This suggests that feeding conditions were favourable throughout the season or that adults were able to compensate for poorer feeding conditions by increasing their parental efforts. The only inter-subcolony difference in chick body mass concerns the higher peak mass in Høystakken than at Moraine in 2008. This could have been a consequence of the small sample size at Høystakken. However, considering the heterogeneity in quality among individuals nesting at the same colony manifested in various reproductive performances reported for kittiwakes (Rissa tridactyla) (Cam and Monnat 2000), it cannot be ruled out that in the unfavourable conditions prevailing at Høystakken prior to hatching, chicks hatched only in the nests of high-quality parents. Those individuals may have provided food of better quantity/quality, which resulted in a high peak body mass. The better conditions at Moraine enabled successful hatching also in the nests of poorer-quality breeders. Their hypothetically worse food provisioning could have decreased the mean peak body mass value in that subcolony.

Both the present study and some others (e.g., Hipfner et al. 2007; Tavecchia et al. 2008) indicate that in seabirds some important traits like hatching success, isotopic niches, fledging mass, adult survival and transience probability may vary within the colony. This variation should be considered when comparing and interpreting data from different colonies, as they are often collected in one patch/ subcolony.

Acknowledgments We are grateful to Lech Iliszko, Wojciech Iliszko and Małgorzata Jakimiak who helped us in nest searching. We would like to thank prof. Lech Stempniewicz, dr Michał Skakuj, dr Børge Moe and two anonymous reviewers for helpful comments in the first version of manuscript. Thanks also go to Liliana Keslinka who helped with area and distances calculation. We appreciate the improvements of English usage made by Peter Senn. Study was supported by grants from Polish Ministry of Science and Higher Education (IPY/25/2007) and Norway through the Norwegian Financial Mechanism (ALKEKONGE, PNRF-234-AI-1/07). Study was performed under the permission of the Governor of Svalbard.

\section{References}

Abraham CL, Sydeman WJ (2004) Ocean climate, euphausiids, and auklet nesting: inter-annual trends and variation in phenology, diet and growth of a planktivorous seabird, Ptychoramphus aleuticus. Mar Ecol Progr Ser 274:235-250

Adams J, Takekawa JY, Carter HR (2004) Stable foraging areas and variable chick diet in Cassin's auklets (Ptychoramphus aleuticus) off southern California. Can J Zool 82:1578-1595 
Benowitz-Fredericks ZM, Shultz MT, Kitaysky AS (2008) Stress hormones suggest opposite trends of food availability for planktivorous and piscivorous seabirds in two years. Deep-Sea Res II 55:1868-1876

Cam E, Monnat J-V (2000) Apparent inferiority of first-time breeders in the kittiwake: the role of heterogeneity among age classes. J Anim Ecol 69:380-394

Cramp S (1998) The complete birds of Western Palearctic on CD-ROM. Oxford University Press, Software@Optimedia, Oxford

de Forest LN, Gaston AJ (1996) The effect of age on timing of breeding and reproductive success in the thick-billed murre. Ecology 77:1501-1511

de Neve L, Fargallo JA, Polo V, Martín J, Soler M (2006) Subcolony characteristics and breeding performance in the Chinstrap Penguin Pygoscelis antarctica. Ardeola 53:19-29

Durant JM, Anker-Nilssen T, Stenseth NC (2003) Trophic interactions under climate fluctuations: the Atlantic puffin as an example. Proc R Soc Lond B Biol Sci 270:1461-1466

Durant JM, Hjermann DØ, Ottersen G, Stenseth NC (2007) Climate and the match or mismatch between predator requirements and resource availability. Clim Res 33:271-283

Elder K, Dozier J, Michaelsen J (1991) Snow accumulation and distribution in Alpine Watershed. Water Resour Res 27:1541-1552

Evans PGH (1981) Ecology and behaviour of the Little Auk Alle alle in west Greenland. Ibis 123:1-18

Gaston AJ, Gilchrist GH, Hipfner MJ (2005) Climate change, ice conditions and reproduction in an Arctic nesting marine bird: Brunnich's guillemot (Uria lomvia L.). J Anim Ecol 74:832-841

Gaston AJ, Gilchrist GH, Mallory ML, Smith PA (2009) Changes in seasonal events, peak food availability, and consequent breeding adjustment in a marine bird: a cause of progressive mismatching. Condor 111:111-119

Gibbs HM, Norman FI, Ward SJ (2000) Reproductive parameters, chick growth and adult 'age' in Australasian gannets Morus serrator breeding in Port Phillip Bay, Victoria, in 1994-95. Emu 100:175-185

Gjerdrum C, Valle'e MJ, St Clair CC, Bertram DF, Ryder JL, Blackburn GS (2003) Tufted puffin reproduction reveals ocean climate variability. Proc Nat Acad Sci USA 100:9377-9382

Grémillet D, Lewis S, Drapeau L, van der Lingen CD, Huggett JA, Coetzee JC, Verheye HM, Daunt F, Wanless S, Ryan PG (2008) Spatial match-mismatch in the Benguela upwelling zone: should we expect chlorophyll and sea-surface temperature to predict marine predator distributions? J Appl Ecol 45:610-621

Harding AMA, Piatt JF, Hamer KC (2003) Breeding ecology of Horned Puffins (Fratercula corniculata) in Alaska: annual variation and effects of El Niño. Can J Zool 81:1004-1013

Harding AMA, Pelt TIV, Lifjeld JT, Mehlum F (2004) Sex differences in Little Auk Alle alle parental care: transition from biparental to parental-only care. Ibis 146:642-651

Harding AMA, Kitaysky AS, Hall ME, Welcker J, Karnovsky NJ, Talbot SL, Hamer KC, Grémillet D (2009) Flexibility in the parental effort of an Arctic-breeding seabird. Funct Ecol 23:348-358

Hatchwell BJ (1991) An experimental study of the effects of timing of breeding on the reproductive success of Common Guillemots (Uria aalge). J Anim Ecol 60:721-736

Hedd A, Ryder JL, Cowen LL, Bertram DF (2002) Inter-annual variation in the diet, provisioning and growth of Cassin's auklets at Triangle Island, British Columbia: responses to variation in ocean climate. Mar Ecol Prog Ser 229:221-232

Hipfner JM (1997) The effects of parental quality and timing of breeding on the growth of nestling Thick-billed Murres. Condor 99:353-360

Hipfner MJ (2008) Matches and mismatches: ocean climate, prey phenology and breeding success in a zooplanktivorous seabird. Mar Ecol Progr Ser 368:295-304
Hipfner MJ, Charette MR, Blackburn GS (2007) Subcolony variation in breeding success in the Tufted Puffin (Fratercula cirrhata): association with foraging ecology and implications. Auk 124:1149-1157

Hipfner MJ, McFarlane-Tranquilla LA, Addison B (2010) Experimental evidence that both timing and parental quality affect breeding success in a zooplanktivorous seabird. Auk 127:195-203

Isaksen K (1995) The breeding population of Little Auk (Alle alle) in colonies in Hornsund and northwestern Spitsbergen. In: Isaksen K, Bakken V (eds) Seabird population in the northern Barents Sea. Meddelelser nr 135. Norsk PolarInstitutt, Oslo

Kitaysky AS, Golubova EG (2000) Climate change causes contrasting trends in reproductive performance of planktivorous and piscivorous alcids. J Anim Ecol 69:248-262

Kitaysky AS, Piatt JF, Wingfield JC (2007) Stress hormones link food availability and population processes in seabirds. Mar Ecol Prog Ser 352:245-258

Koenig WD (1982) Ecological and social factors affecting hatchability of eggs. Auk 99:526-536

Konarzewski M, Taylor JRE (1989) The influence of weather conditions on growth of Little Auk Alle alle chicks. Ornis Scand 20:112-116

Mínguez E, Fargallo JA, de León A, Moreno J, Moreno E (1998) Age-related variations in bill size of chinstrap penguins. Waterbirds 21:66-68

Moe B, Stempniewicz L, Jakubas D, Angelier F, Chastel O, Dinesse F, Gabrielsen GW, Hanssen F, Karnovsky NJ, Rønning B, Welcker J, Wojczulanis-Jakubas K, Bech C (2009) Climate change and phenological responses of two seabird species breeding in the high-Arctic. Mar Ecol Prog Ser 393:235-246

Moline MA, Karnovsky NJ, Brown Z, Divoky GJ, Frazer TK, Jacoby CA, Torres JJ, Fraser WR (2008) High latitude changes in ice dynamics and their impact on polar marine ecosystems. Ann NY Acad Sci 1134:267-319

Morbey YE, Ydenberg RC (1997) Intraspecific variability in nestling growth and fledging behavior of Cassin's Auklets at Triangle Island, British Columbia. Condor 99:361-371

Rodway MS, Chardine JW, Montevecchi WA (1998) Intra-colony variation in breeding performance of Atlantic puffins. Colon Waterbirds 21:171-184

Shultz MT, Piatt JF, Harding AMA, Kettle AB, Van Pelt TI (2009) Timing of breeding and reproductive performance in murres and kittiwakes reflect mismatched seasonal prey dynamics. Mar Ecol Prog Ser 393:249-260

Spurr EB (1975) Breeding of the Adelie Penguin (Pygoscelis adeliae) at Cape bird. Ibis 117:324-338

Stempniewicz L (1980) Factors influencing the growth of the Little Auk, Plautus alle (L), nestlings on Spitsbergen. Ekol Pol 28:557-581

Stempniewicz L (1981) Breeding biology of the Little Auk, Plautus alle in the Hornsund region, SW Spitsbergen. Acta Ornithol 18:141-165

Stempniewicz L (1986) Factors causing changes in the rhythm of attendance of the Little Auks, Plautus alle (L.), at a colony during the breeding season in Svalbard. Ekol Pol 34:247-263

Stempniewicz L (1995) Predator-prey interactions between Glaucous Gull Larus hyperboreus and Little Auk Alle alle in Spitsbergen. Acta Ornithol 29:155-170

Stempniewicz L (2001) Alle alle Little Auk. BWP Update. J Birds Western Palearctic 3:175-201

Stenseth NC, Ottersen G, Hurrell JW, Mysterud A, Lima M, Chan K-S, Yoccoz NG, Ådlandsvik B (2003) Studying climate effects on ecology through the use of climate indices: the North Atlantic Oscillation, El Niño Southern Oscillation and beyond. Proc R Soc Lond B 270:2087-2096 
Suryan RM, Irons DB, Brown ED, Jodice PGR, Roby DD (2006) Sitespecific effects on productivity of an upper trophic level marine predator: bottom-up, top-down, and mismatch effects on reproduction in a colonial seabird. Prog Oceanogr 68:303-328

Sydeman WJ, Bradley RW, Warzybok P, Abraham CL, Jahncke J, Hyrenbach DK, Kousky V, Hipfner MJ, Ohman MD (2006) Planktivorous auklet Ptychoramphus aleuticus responses to ocean climate, 2005: unusual atmospheric blocking? Geophys Res Lett 33:L22S09.1-L22S09.5

Szor G, Berteaux D, Gauthier G (2008) Finding the right home: distribution of food resources and terrain characteristics influence selection of denning sites and reproductive dens in arctic foxes. Polar Biol 31:351-362

Tavecchia G, Minguez E, De Leo A, Louzao M, Oro D (2008) Living close, doing differently: small-scale asynchrony in demography of two species of seabirds. Ecology 89:77-85
Tenaza R (1971) Behaviour and nesting success relative to nest location in adélie penguins Pygoscelis adeliae. Condor 73:81-92

Welcker J, Harding AMA, Kitaysky AS, Speakman JR, Gabrielsen GW (2009) Daily energy expenditure increases in response to low nutritional stress in an Arctic-breeding seabird with no effect on mortality. Funct Ecol 23:1081-1090

Yorio P, Boersma PD (1994) Causes of nest desertion during incubation in the Magellanic Penguin (Spheniscus magellanicus). Condor 96:1076-1083

Zach R (1988) Growth-curve analysis: a critical reevaluation. Auk 105:208-210 